\title{
Methods of Measuring of Residual Stresses and Evaluation of Residual State of Functional Surfaces by X-Ray Diffractometric Methods
}

Dana Stančeková, Ján Šemcer, Michal Derbas, Tomáš Kurňava

University of Zilina, Faculty of Mechanical Engineering, Univerzitná 1, 010 26, Žilina Slovakia, Slovak Republic, dana.stancekova@fstroj.uniza.sk, jan.semcer@fstroj.uniza.sk

Objectives of the paper are intended to implement system solutions to nondestructive evaluation of technologies associated with verification of equipment, preparation of samples with different types of functional properties and their subsequent evaluation of various scientific methods. The main objective of experiments is to transform new knowledge of non-destructive technologies into industrial practice in the evaluation of functional properties of the surface and subsurface layers of these technologies. The aim is to increase the level of cooperation $R \& D$ institutions with social and economic practices through knowledge and technology transfer, and thus contribute to increased economic growth of the regions in Slovakia. This work is related to the project with the University of Zilina OPVaV-2009/2.2/04-SORO number (26220220101). Its name is Intelligent System for Nondestructive Technologies to evaluation of functional properties of parts of $\mathrm{X}$-ray-diffractometry. The main objective of the project is to transform new nondestructive technology for knowledge transfer to industry for evaluation of functional parts in surface and subsurface layers of non-destructive techniques.

Keywords: residual stress, X - ray diffractometry, machining

\begin{abstract}
Aknowledgement
The article was made under support grant project OPVaV-2009/2.2/04-SORO number (26220220101). His name is Intelligent system for nondestructive technologies to evaluation of functional properties of parts of $X$-ray diffractometry and VEGA 1/0773/12 Implementation of technical ceramic material research to increase the innovation of hybrid products
\end{abstract}

\section{References}

[1] BATORA, B., VASILKO K. (2000). Obrobene povrchy, technologicka dedicnost, funkcnost. pp. 107. Trencin..

[2] CEP, R., KOURIL, K., MRKVICA, I., JANASEK, I., PROCHAZKA, J. (2010). Test of tools Kyocera in conditions discontinuous cuts, pp. 51-58. Strojirenska technologie, vol. XV, 2010/3.

[3] CEP, R., JANASEK A., PETRU J., CEPOVA L., CZAN A., VALICEK J. (2013). Hard Machinable Machining of Cobalt-based Superalloy p. 226-231. ManufacturingTechnology XIII/13 . UJEP: Ústi n. Labem.

[4] CZAN, A., STEKLAC, D., STANCEKOVA, D. (2005). Tools for High Productive Machining of Bearing Materials By Turning. Tools Zlin

[5] CZAN, A., TILLOVA, E., SEMCER, J., PILC, J. (2013). Surface and subsurface residual stresses after machining and their analysis by X-ray diffraction. pp. 69-76. Komunikacie, Volume 15, Issue 2

[6] HOLESOVSKY F., NAPRSTKOVA N., NOVAK M. (2012). GICS for grinding process optimization, pp. 22-26. ManufacturingTechnology XII/12. UJEP: Ústi n. Labem.

[7] SAJGALIK, M., CZAN, A. (2011). Studying of processes in cutting zone by non-destructive methods. Technological Engineering, volume 8, number 2

[8] KANDIL, F.A., LORD, J.D., FRY, A.T., GRANT, P.V. (2001). A Review of Residual Stress Measurement Methods, pp. 25-32. A Guide to Technique Selection, NPL Report MATC(A)04

[9] KORMUNDA M. (2010). X-Ray Photoelectron Spectroscopy for industrial applications, pp. 34-36. Manufacturing Technology. Vol. X.

[10] MONKA, P.; MONKOVÁ, K. (2009). Process plans design in relation to increasing of production efficiently, pp. 239-244Scientific Bulletin, 23, C.

[11] NOVÁKOVÁ, J., PETŘKOVSKÁ, L., BRYCHTA, J., STANČEKOVÁ, D. (2009). Influence of Cutting Parameters on Integrity Surface At High Speed Cuttin, pp. 203-209. Transactions of the VŠB - Technical University of Ostrava. Mechanical Series, IV/ 1.

[12] PILC, J.- VASILKO, K. (2013). Development and applications of a rotating turning tool, pp. 226-231. ManufacturingTechnology XIII/13. UJEP: Ústi n. Labem. 
[13] SCHULZE V. - AUTENRIETH H. - DEUCHERT M. - WEULE H. (2010). Investigation of surface near residual stress states after micro-cutting by finite element simulation, pp. 117-120. CIRP Annals - Manufacturing Technology 59

[14] VRÁNA M, MIKULA P, NOVÝ Z, (1998). Neutron Diffraction Measurements of Strain/Stress State Induced by a Weld Deposited Pass.

[15] WITHERS PJ, BHADESHIA (2000) [on line] HKDH, Overview: Residual Stress, Part 1-Measurement Techniques, Materials Science and Technology; 17:355. [Accessed: 9.02.2004] Avalaible at www: $<$ http://www.msm.cam.ac.uk/phase-trans/2001/mst4640a.pdf>. 